\title{
KOSTUM PRAJURIT KRATON YOGYAKARTA KAJIAN PERAN DAN NILAI SIMBOLIK
}

\author{
Septianti ${ }^{1}$ (ceptianti27@gmail.com, Pascasarjana Institut Seni Indonesia Yogyakarta)
}

\begin{abstract}
Each country has a military device, but if other countries use it as a means of maintaining the sovereignty of the region and its people, but in Yogyakarta is different. Soldiers of the palace in Yogyakarta have a role as a completeness in the ceremonies and on other occasions made by the Palace. In addition it will discuss four soldiers who use lurik as the main ingredient in the costum that is, soldiers Patang, Jagakarya, Ketanggung, and Mantrijero. The four selected soldiers have similarities to the motives imposed despite having different attributes on each costume, whether there is a supporting color on the black or red costume. The method used qualitative method with descriptive approach. While the study used in the form of role values and symbolic theories that exist in the costume. The semiotics theory was to be used belongs to Charles S. Peirce. Semiotics has a definition as a study of signs, essentially a study of codes, ie any system that allows us to view certain entities as signs or as meaningful. Therefore, the value of symbols that can be picked from this costume the existence of cultural values that can not be separated, such as lurik which mutually forwarded again with other colors, the depiction of loyalty of the warrior with his master who do not get the existence of estrangement.
\end{abstract}

Keywords: Costume, soldiers, Kraton Yogyakarta

\begin{abstract}
ABSTRAK
Setiap negara memiliki perangkat militer, namun bila negara lain menggunakannya sebagai alat mempertahankan kedaulatan wilayah dan bangsanya, tapi di Yogyakarta berbeda. Prajurit kraton di sini memiliki peran sebagai suatu kelengkapan dalam upacara-upacara dan pada kesempatan lain yang dilakukan oleh Kraton .Selain hal itu nanti akan hanya membahas empat prajurit yang menggunakan lurik sebagai bahan utama dalam kostumnya yaitu, prajurit Patang puluh, Jagakarya, Ketanggung, dan Mantri jero. Keempat prajurit yang dipilih memiliki kesamaan akan motif yang dikenakan walaupun memiliki atribut-atribut yang berbeda pada setiap kostumnya, baik ada yang memiliki warna pendukung pada kostum hitam maupun merah. Metode yang akan digunakan metode kualitatif dengan pendekatan deskriptif. Sedangkan kajian yang akan digunakan berupa nilai peran dan teori simbolik yang ada pada kostumnya. Teori semiotika yang akan digunakan milik Charles S. Peirce. Semiotika memiliki definisi sebagai suatu kajian tanda-tanda, pada dasarnya merupakan sebuah studi atas kodekode, yaitu sistem apapun yang memungkinkan kita memandang entitas-entitas tertentu sebagai tanda atau sebagai suatu yang bermakna. Maka dari itu nilai simbol yang dapat dipetik dari kostum ini adanya nilai budaya yang tak lepas, seperti lurik yang saling diteruskan lagi dengan warna lain, penggambaran kesetiaan prajurit dengan tuannya yang jangan sampai akan adanya kerenggangan.

Kata kunci: Kostum, prajurit, Kraton Yogyakarta
\end{abstract}




\section{PENDAHULUAN}

Majunya perkembangan budaya pada era globalisasi ini, mulai hilangnya kesadaran generasi muda akan budaya pada masa lampau. Indonesia merupakan salah satu negara yang memiliki keanekaragaman budaya, suku bangsa, bahasa, tradisi, pakaian adat, dan banyak lagi. Bila berbicara pakaian, salah satu kostum yang familiar yaitu, kostum tradisional Prajurit Kraton Yogyakarta.

Sama halnya dengan negara lain, di Yogyakarta memiliki perangkat militer sebagai alat mempertahankan untuk menjaga kedaulatan wilayah dan bangsanya. Namun, berbeda negara lain, prajurit kraton di sini memiliki peran sebagai suatu kelengkapan dalam upacara-upacara yang dilakukan di kraton dan pada kesempatan lain yang dilakukan oleh Kraton. Hal ini biasanya dilakukan pada saat adanya tamu dari luar negeri yang berkunjung ke Kraton Yogyakarta, tapi pada zaman sekarang memiliki fungsi sebagai menunjang suksesnya kepariwisataan dari kesultanan Yogyakarta.

Keberadaannya Prajurit Kraton sendiri telah ada sejak ratusan tahun. Bermula dari kerajaan Mataram Islam awal yang beribukota di Kotagede dan di Pleret, baik itu abdi dalem maupun prajurit telah ada di Kraton, dikarenakan sebagai bentuk strategi pertahanan pada masa itu. Kebenarannya sendiri dapat dilihat dari dari fakta sejarah pada masa periode awal kerajaan Mataram, yaitu pada masa Penembahan Senopati (1585- 1601 M) dan Hanyakrawati (1601-1613 M) sampai pada masa pemerintahan Sultan Agung (1613- 1645 M), saat itu Kerajaan Mataram dikenal sebagai kerajaan yang memiliki prajurit yang kuat dan tangguh. Pada masa Sultan Agung prajurit Mataram melakukan penyerbuaan ke benteng VOC atau kumpeni di Batavia, tahun 1628 M dan 1629 M.
Adanya Prajurit Kraton Ngoyagyakarta Hadiningrat pada saat peristiwa munculnya "perang Mangkubumen" dan yang terakhir adanya Perjanjian Giyanti. Karena hal itu, Paku Buwana III dengan Pengeran Mangkubumi (putra Amangkurat IV) pada 13 pebuari 1755 M, Kerajaan Mataram dibagi menjadi dua bagian, yaitu Kesunan Surakarta dan Kesultanan Ngoyogyakarta

Prajurit Kraton pada awalnya berjumlah 26 bregada, sejak kepemimpinan Sultan Hamengku Buwono V Prajurit Kraton menjadi tiga belas bregada. Hal ini berlanjut pada masa Sultan Hamengku Buwono VII dan VII jumlah pasukan menjadi dua belas bregada. Namun setelah sempat bubar pada masa Kesultanan Hamengku Buwono IX pada tahun 1956. Tapi pada masa Sultan Hamengku Buwono $X$ terdapat sepuluh bregada.

Kostum tradisional pada Prajurit Kraton memiliki beberapa bagian. Dan secara struktur tiap prajurit memiliki identifikasi yang beranekaragam baik secara sebutan nama depan, struktur prajurit maupun panjipanjinya. $\mathrm{Di}$ sini penulis tidak akan membahas mengenai keseluruhan prajurit namun hanya empat yaitu, prajurit Patang puluh, Jagakarya, Ketanggung, dan Mantri jero . Dari pengamatan yang dilakukan prajurit ini memiliki motif lurik yang sama karena hal itu, penulis mengambil empat prajurit tersebut.

Pemilihan dan penggunaan kostum tradisional Prajurit Kraton, baik bahan, bentuk senjata dan atribut yang dikenakan serta tata cara tertentu saat melakukan kegiatan seremonial menunjukan adanya nilai-nilai budaya yang kaya dan luas. Keempat prajurit yang dipilih memiliki kesamaan akan motif yang dikenakan walaupun memiliki atributatribut yang berbda pada setiap kostumnya, baik ada yang memiliki warna pendukung pada kostum hitam maupun merah. Karena hal itulah, penulis akan mengkaji perihal 
mengenai keempat prajurit tersebut, baik atribut yang mereka kenakan maupun motif yang berbeda pada tiap prajuritnya.

Unsur-unsur yang dikenakan para Prajurit Kraton bila, diamati terlihat teknis baik itu topi untuk melindungi kepala dari sengatan matahari ataupun melindungi dari yang lain misalnya. Sebaliknya pada tombak trisula dapat mengambarkan nilai-nilai religius sebagai waos atau dwaja salah satu pasukan, dan pakaian yang mereka kenakan dapat memiliki sifat sosial yang dapat menunjukan perilaku maupun kedudukan tertentu.

Selain hal itu terjadi, pada awal paragraf telah diterangkan adanya suatu pergeseran peran dan fungsi yang dimiliki Prajurit Kraton Yogyakarta, dari prajurit pertahanan keamanan ke prajurit seremonial akan mempengaruhi perubahan tugas dan kewajiban Prajurit Kraton sendiri yang mana dititik beratkan sebagai seremonial Kraton .

Dari hal-hal yang telah disebutkan itu, nantinya dalam penulisannya akan merujuk pada Prajurit Kraton Yogyakarta dengan segala atributnya, panji-panji, kostum dan berbagai perlengkapan secara simbolik. Yaitu nilai-nilai simbolik seperti apa yang terkandung di dalamnya, baik secara sosial, budaya, maupun religius nantinya. Pemecahan latar belakang yang akan dicari nantinya berupa, apa peran, fungsi, dan nilai simbolik yang ada pada kostum Prajurit Kraton Yogyakarta dan bagaimana sejarah awalnya kostum tradisional Prajurit Kraton Yogyakarta?

Kajian pustaka yang terkait dengan pembahasan ini ada beberapa disertasi yang mengangkat mengenai Prajurit Kraton Yogyakarta diantaranya sebagai berikut, milik Anna Galuh Indreswari mengangkat mengenai Kostum Prajurit Kraton pada masa pemerintahan Sri Sultan Hamengku Buwono $X$ dalam pembahasannya mengenai fungsi dan bentuk kostum prajurit Kraton Yogyakarta seperti apa bentuk busananya, apa saja fungsi busananya, dan bagaimana hubungannya dengan seni wisata. Kraton Yogyakarta mulai mengalami kemunduran politik sejak kedatangan bangsa barat di wilayahnya. Tekanan politik yang dilakukan pihak barat mempengaruhi kekuasaan Raja, terutama dalam mengatur jalannya pemerintahan. Raja yang tidak berkuasa mengatur pemerintahan kerajaannya, melakukan perlawanan dalam bentuk kebudayaan. Bentuk kebudayaan termasuk di dalamnya adalah kostum prajurit Kraton Yogyakarta. Bentuk kostum yang sudah dipengaruhi unsur barat, menghasilkan gaya kostum yang baru. Penelitian ini memerlukan metode pendekatan untuk menemukan jawaban pertanyaan.

Metode yang digunakan adalah penelitian kualitatif dengan pendekatan multidisiplin. Pendekatan multidisiplin berguna untuk meneliti suatu rancangan karya seni dari sudut pandang disiplin ilmu yang berbeda-beda. Berbagai disiplin ilmu tersebut, adalah: sejarah, antropologi, arkeologi, komunikasi dan sosiologi.

Penelitian dengan teori-teori yang relevan dari berbagai disiplin ilmu ini, mampu menghasilkan analisa yang tepat dan akurat mengenai bentuk dan fungsi kostum prajurit Kraton Yogyakarta. Penelitian tentang kostum prajurit Kraton Yogyakarta menghasilkan kesimpulan bahwa bentuk dan fungsi kostum berhubungan erat dengan upacara adat Kraton, yaitu: Garebeg. Upacara adat Garebeg diselenggarakan secara ajeg di Kraton Yogyakarta. Garebeg berkaitan dengan agenda seni wisata di Daerah Istimewa Yogyakarta.

Dalam kajian lainnya juga terdapat pembahasan mengenai kostum Prajurit Kraton Yogyakarta dalam manuskrip kostum tradisional Jawa pada tulisann miliki Sri Harti merupakan laporan tesis yang membahas menganai manuskrip mengandung harta 
kultural yang perlu dipelajari generasi kini dan mendatang. Makalah ini diangkat dari hasil penelitian tentang kostum tradisional dalam manuskrip-manuskrip Jawa yang pada waktu ini memasuki tahap tahun kedua. Tujuan penulisan makalah adalah mendeskripsikan jenis, ragam, dan atribut serta cara pemakaian kostum tradisional yang terdapat dalam manuskrip manuskrip Jawa yang tersimpan di Yogyakarta.

Penelitian yang dilakukan menggunakan pendekatan kualitatif deskriptif dan filologi modern. Sebagian hasil penelitian ini dipaparkan bahwa kostum keprajuritan didesain dan dirancang secara teliti dengan memperhatikan perbedaan tingkat sosial dan pangkat dalam kerajaan. Kostum keprajuritan untuk raja, pangeran, dan para bendara lebih mewah dibandingkan dengan kostum keprajuritan untuk abdi dalem, panewu, dan bupati. Semua baju keprajuritan memakai celana panji, baju sikepan, kuluk dan dhestar, kaos kaki hitam, sepatu hitam, dan dua buah keris, baranggah dan gayaman.

$\mathrm{Di}$ atas merupakan beberapa laporan yang ditemukan melalui media internet yang merupakan suatu laporan penelitian yang akan sebagai landasan untuk agar tidak terjadi penggandaan maupun penjiplakan. Dalam beberapa laporan tersebut kebanyakan membahasan fungsi dan bentuk dan sosial politik yang ada pada kostum prajurit tersebut. Tapi dalam laporan ini nantinya akan mebahas mengenai peran seperti apa yang ada pada busan tersebut dan nilai simbol apakah yang ada tiap kostum kostum tersebut.

Sedangkan dalam pemilihan landasan teori menggunakan kajian budaya yang nantinya ada kajian simbolik yang ada di dalamnya. Dalam kajian budaya yang akan digunakan berupa nilai filosofi dan simbolik yang terdapat pada kostum prajurit Kraton Yogyakarta.
Teori yang akan digunakan seperti yang telah dijelaskan pada latar belakang masalah, yaitu teori semiotika. Teori semiotika yang akan digunakan milik Charles S. Peirce. Semiotika memiliki definisi sebagai suatu kajian tanda-tanda (the study of signs), pada dasarnya merupakan sebuah studi atas kodekode, yaitu sistem apapun yang memungkinkan kita memandang entitasentitas tertentu sebagai tanda-tanda atau sebagai suatu yang bermakna (Scholes, 1982: 2).

Bagi Pierce (Pateda, 2001:44), tanda "is something which stands to somebody for something in some respect or capacity." Sesuatu yang digunakan agar tanda bisa berfungsi, oleh Pierce disebut ground. Konsekuensinya, tanda (sign atau representamen) selalu terdapat dalam hubungan triadic, yakni ground, object, dan interpretant. Atas dasar hubungan ini, Pierce mengadakan klasifikasi tanda. Tanda yang dikaitkan dengan ground yaitu pengetahuan tentang sistem tanda dalam suatu masyarakat dibaginya menjadi qualisign, sinsign, dan legisign. Berdasarkan objeknya, Pierce membagi tanda atas icon (ikon), index (indeks), dan symbol (symbol). Berdasarkan interpretant tanda (sign, representamen) dibagi atas rheme, dicent sign atau dicisign dan argument. Hal yang terpenting dalam proses semiosis adalah bagaimana makna muncul dari sebuah tanda ketika tanda itu digunakan orang saat berkomunikasi.

\section{METODE PENELITIAN}

Dalam metode yang digunakan untuk memperoleh data-data yang akan mendukung jurnal yaitu menggunakan metode kajian pustaka dan melakukan observasi terhadap kajian yang akan dicari nantinya.

Metode yang digunakan dalam pembahasan ini menggunakan metode kualitatif dengan pendekatan deskriptif. 
Metode deskriptif yang akan digunakan untuk membuat deskripsi, gambaran, atau lukisan secara sistematis, faktual dan akurat mengenai fakta-fakta, sifat-sifat serta hubungan antar fenomena yang diselidiki. Sedangkan dalam pengumpulan datanya menggunakan penelitian perpustakaan yaitu, kegiatan mengamati berbagai literatur yagn berhubungan dengan pokok permasalahan yang diangkat baik itu berupa buku, makalah ataupun tulisan yang sifatnya membantu sehingga dapat dijadikan sebagai pedoman dalam proses penelitian.

Keberadaan prajurit Kraton mempunyai sejarah yang panjang, yang telah mengalami keadaan genting. Prajurit kerajaan telah ada sejak ratusan tahun yang lalu. Sejaka masa kerajaa Mataram Islam awal beribukota di Kotagede dan do Pleret, keberadaannya abdi dalem dan prajurit-prajurit Kraton telah terbukti memiliki peran penting dari strategitaktik pertahanan militer. Pada masa mataram Islam, memiliki kerajaan yang kuat membuat kesatuan Bregada atau abdi dalem pasukan prajurit Kraton yang kuat pula.

Pada masa dinansti-dinasti penerus kerajaan Mataram sampai periode abad ke 18 misalnya prajurit sebagai kekuatan militer tetap berada pada posisi strategi dan menjadi salah satu tolak ukur kekuatan, keruntuhan, dan kemampuan pertahanan pada masa itu.

Latar belakang adanya prajurit Kraton Yogyakarta terkait dengan konflik yang memunculkan peristiwa "perang Mangkubumen" anatara tahun 1746 - 1755 $M$ yang terkait dengan adanya perjanjian Giyanti antara Sri Sunan Paku Buwana III dengan Pangeran Mangkubumen. Dalam sejarah mengatakan keberhasilan perjuangan Hamengku Buwana I tidak lepasa dari dukungan aliansi prajurit, kerabat, kelompokkelompok prajurit dibawah pimpinan Rangga Prawirasentika. Ini merupakan sejarah singkat mengenai pentingnya prajurit Kraton pada masa-masa itu.

Pasukan prajurit Kraton Yogayakarta memiliki bebrapa kelompok pasukan yang pertama, kelompok pasukan yang dimiliki oleh Kraton. Kedua, pasukan yang dimiliki oleh Kadipati Anom, dan terakhir pasukan yang dimiliki oleh kepatihan. Selain hal tersebut nama-nama pasukan tidak sekedar berkaitan dengan afiliasi pasukan tersebut, tapi memiliki landasan filosofi tertentu, seperti nama Wirabraja dan Prawiratama memiliki arti kewiraan dan kemeliteran.

\section{HASIL DAN PEMBAHASAN}

\section{A. Identifikasi dan Simbolik Pada Prajurit Kraton Yogyakarta Saat Ini}

1. Prajurit Patang puluh

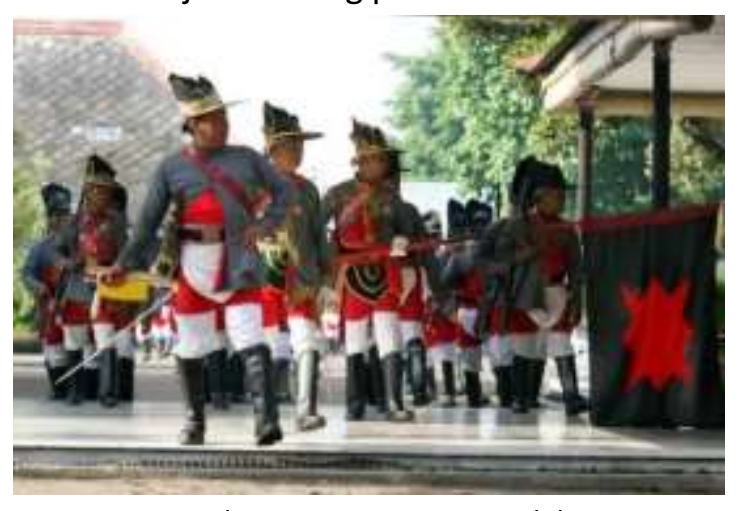

Gambar 3. Prajurit Patang puluh

(Sumber: http://www.pulsk.com, pukul.16.01)

Prajurit Patang puluh dulu berada di sebelah barat daya Kraton Yogyakarta, prajurit tersebut terkenal dengan keberaniannya dan ketanggung nya saat di medan pertempuran, sehingga keberadaan prajurit patang puluh ini menjadi andalan saat bertempur.

Namanya sendiri brlum diketahui apakah merupakan jumlah pasukan yang dulunya memiliki 40 personil. Sedangkan pada acara Grebeg prajurit ini berada pada urutan ke tiga dalam defile.

Prajurit Patang puluh yang ada saat ini di Kraton Yogyakarta terdiri atas 4 perwira 
berpangkat panji, 8 bintara berpangkat sersan serta 72 prajurit dan 1 pembawa bendera. Bendera yang menjadi panji panji prajurit patang puluh dinamakan Cokrogora berbentuk empat persegi panjang dengan warna dasar hitam ditengahnya terdapat bintang segi enam berwarna merah. Cakragora berasal dari bahasa sansekerta cakra yang berarti senjata yang berbentuk gerigi dan gora yang berarti dahsyat atau menakutkan. Dan secara filosofi arti panji atau bendera tersebut adalah prajurit yang mempunyai kekuatan yang sangat luar biasa sehingga semua musuh seperti apapaun dapat dikalahkan. Untuk dwaja bernama Kanjeng Kyai Trisula.

Pakaian atau seragam yang dikenakan prajurit patang puluh adalah berbentuk sikepan dengan corak lurik khas patang puluh yakni lurik kemiri, dengan celana pendek warna merah diluar celana panjang putih. Destar wulung, lonthong atau ikat pinggang dalam berwarna merah, kamus atau ikat pinggang luar berwarna hitam, Rompi warna merah dengan tutup kepala berupa songkok berwarna hitam serta sepatu fantopel hitam dengan kaos kaki hitam.

Persenjataan prajurit patang puluh berupa bedil dan keris branggah. Sedangkan alat musik terdiri dari tambur, seruling serta terompet. Iringan musik saat berjalan lambat dan digayakan menggunakan Mares Gendero dan untuk berjalan cepat menggunakan mares Bulu-bulu. Ciri nama-nama para prajurit dalam bregada ini selalu disertai dengan kata "Himo".

Wilayah markas prajurit Patang puluh saat ini sebagai sebuah kampung dengan nama Patang puluhan. Di atas merupakan identifikasi mengenai prajurit Patang puluh.

\section{Prajurit Jagakarya}

Prajurit Jagakarya merupakan barisan nomor empat dalam defile setelah prajurit
Wirobrojo, Prajurit Dhaeng dan Prajurit Patang puluh. Jagakarya berasal dari kata Jaga dan Karyo, Jaga yang diambil dari bahasa sansekerta berarti menjaga sedangkan karyo berasal dari bahasa kawi yang berarti tugas atau pekerjaan. Sehingga secara filosofi keberadaan prajurit Jagakarya merupakan pasukan yang mengemban tugas untuk menjaga serta mengamankan jalannya pelaksanaan pemerintahan didalam kerajaan.

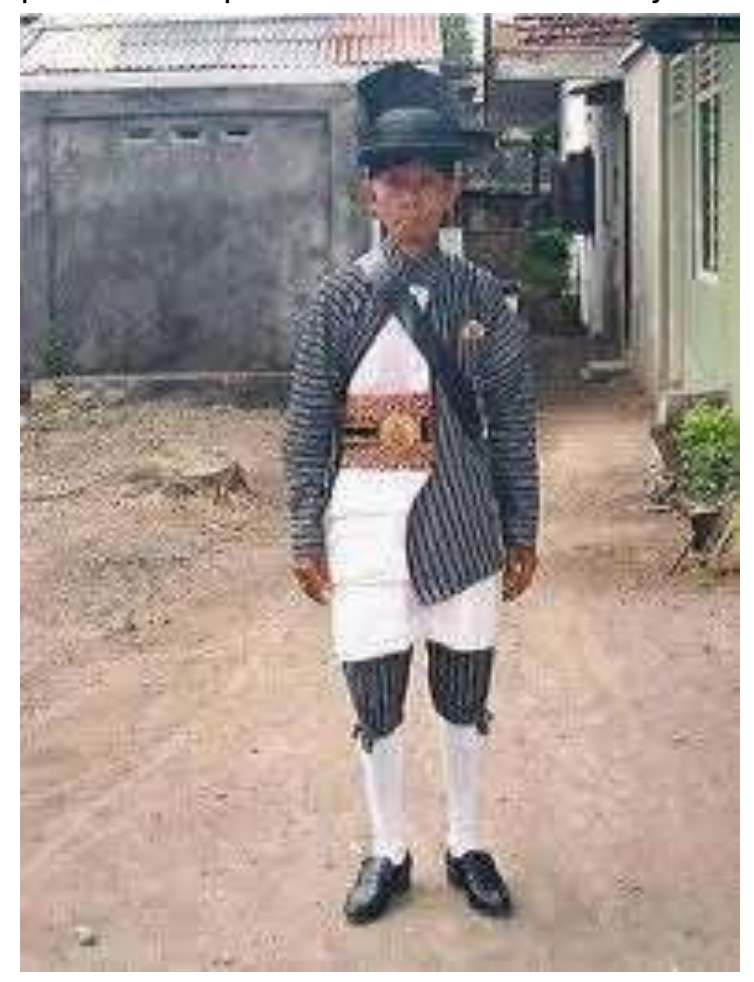

Gambar 4. Prajurit Jagakarya

(Sumber: http://www.pulsk.com, pukul.16.01)

Panji panji atau bendera prajurit Jagakaryo adalah papasan. Kata Papasan berasal dari kata nama tumbuhan atau burung papasan. Pendapat lain Papasan berasal dari kata dasar 'papas' menjadi 'amapas' yang berarti 'menghancurkan' (Wojowasito, 1977:190). Bendera ini berbentuk empat persegi panjang dengan warna dasar merah dan pada bagian tengahnya berupa lingkaran warna hijau. Dengan demikian secara filosofi papasan mempunyai makna bahwa prajurit Jogokaryo dengan lambang Bendera papasan merupakan pasukan pemberani 
yang dapat menghancurkan musuh dengan semangat yang teguh.

Seragam dari prajurit Jagakaryo adalah Tpo Hitam bentuk tempelengan yang terlihat seperti kapal terbalik, Destar atau ikat kepala berwarna wulung, rompi berwarna crem atau kuning emas, beskap lurik lupat lapis warna merah, sayak lurik, lonthong atau ikat pingang dalam warna merah dan Kamus atau ikat pinggang luar berwarna hitam. Sedangkan Celana panji lurik, menggunakan kaos kaki panjang, sepatu fantopel warna hitam.

Persenjataan yang dipergunakan oleh Prajurit Jagakaryo berupa bedil, tombak serta keris branggah. Sedangkan perangkat music yang dipakai adalah tambur, seruling dan terompet untuk memainkan music iringan saat berjalan dan digayakan dengan menggunakan Mares Slanggunder dan untuk jalan cepat menggunakan mares Tamengmaduro. Bregada Prajurit Jogokaryo dilengkapi dengan senjata berupa senapan api dan tombak. Ciri nama-nama para prajurit dalam bregada ini selalu disertai dengan kata "Parto".

Nama Jagakaryo kemudian dipakai nama sebuah perkampungan yang dinamakan Jogokaryan yang letaknya di sebelah selatan Kraton Yogyakarta sebelum panggung krapyak.

\section{Prajurit Ketanggung}

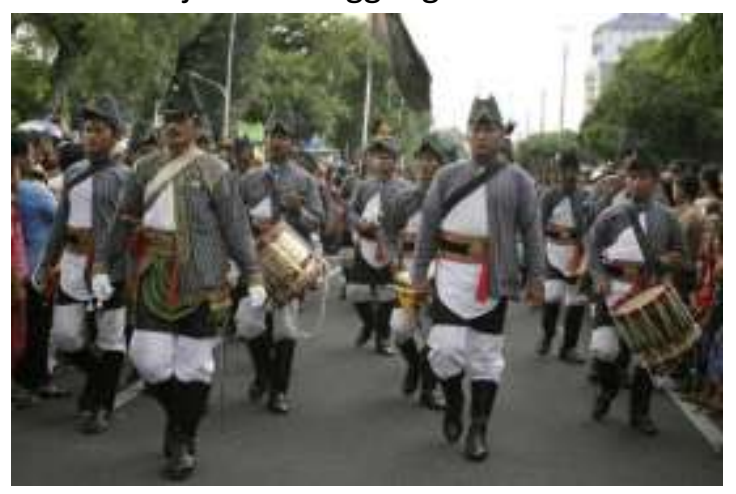

Gambar 5. Prajurit Ketanggung

(Sumber: http://www.pulsk.com, pukul.16.01)
Pada zamannya dulu keberadaan prajurit Ketanggung bertanggung jawab atas lingkungan Kraton dan sebagai penuntut perkara dan mempunyai kewajiban mengawal keberada Raja jika melakukan kunjungan keluar Kraton . Nama ketanggung berasal dari kata tanggung dan mendapat awalan ke yang berartibeban, berat sedangkan ke memberikan tekanan menyangatkan sehingga secara filosofi prajurit ketanggung mempunyai tanggung jawab yang sangat berat. Keberadaan prajurit ini terdiri atas 4 perwira berpangkat panji, 8 bintara berpangkat sersan, 72 prajurit dan 1 pembawa dwaja yang bernama Kanjeng Kyai Nanggolo.

Seragam yang digunakan prajurit ketanggung adalah berbentuk sikepan, dengan corak lurik khas ketanggung serta celana pendek hitam diluar celana panjangputih, sepatu laras hitam dan topi mancungan berwarna hitam dengan hiasan bulu bulu ayam.

Panji atau bendera prajurit Ketanggung adalah Cakraswandana berbentuk empat persegi panjang dengan dasar warna hitam pada bagian tengah terdapat gambar bintang bersegi enam dengan warna putih. Cakraswandana berasal dari kata cakra dari bahasa sansekerta yang berarti senjata berbentuk roda bergerigi. Dan kata swandana yang berasal dari bahasa kawi berarti kendaraan atau kereta sehingga secara filosofi berarti pasukan yang membawa senjata cakra yang dahsyat yang akan memporak porandakan musuh.

Persenjataan yang dipakai oleh Prajurit Ketanggung adalah senjata api dengan bayonet terhunus serta tombak. Untuk peralatan music yang digunakan berupa tambur, seruling, terompet, dan bende. Musik untuk berjalan lambat dan digayakan menggunakan mares Bergolo Milir sedangkan untuk berjalan cepat menggunakan Mares 
Lintrik Emas. Keberadaan nama prajurit Ketanggung ini menjadi nama kampung Ketanggung . Ciri nama-nama para prajuritnya selalu disertai dengan kata "Joyo".

4. Prajurit Mantri jero

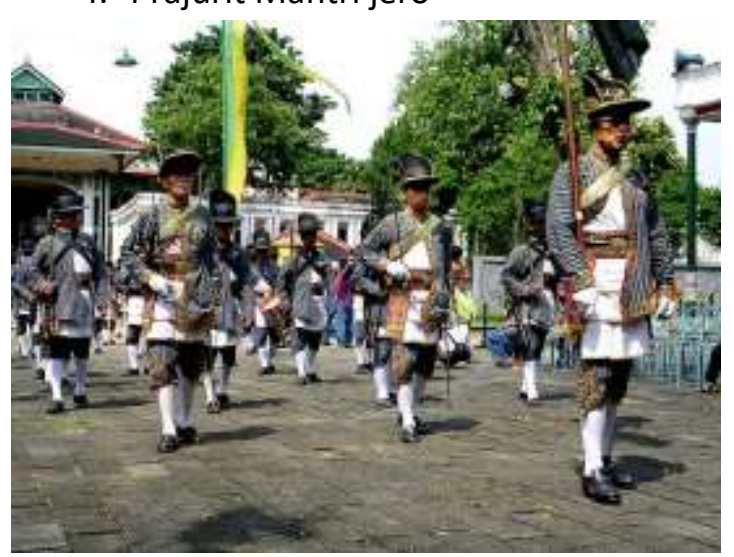

Gambar 6. Prajurit Mantri jero

(Sumber: http://www.pulsk.com, pukul.16.01)

Prajurit Mantri jero dahulunya beranggotakan menteri menteri di dalam Kraton yang bertugas untuk berdiri sebagai hakim yang memutuskan perkara. Tugas yang diemban adalah mengawal sultan pada saat diselenggarakan upacara Jumengan Dalem Nata di Bangsal Sitihinggil. Kata mantri jero berasal dari kata mantra dari bahasa sansekerta yang berarti juru bicara, menteri merupakan jabatan di atas bupati yang memiliki wewenang dalam salah satu struktur pemerintahan sedangkan jero berarti dalam. Secara harfiah Manterijero berarti Juru bicara atau menteri didalam. Sedangkan secar filosofi Mantri jero bermakna pasukan yang mempunyai wewenang ikut ambil bagian dalam memutuskan segala sesuatu hal dalam lingkungan Kraton .

Pasukan ini terdiri dari 8 perwira berpangkat panji 8 bintara berpangkat sersan , 64 prajurit dan 1 prajurit pembawa duaja yang bernama kanjeng Kyai Cokro. Sedangkan komandan pasukan tersebut berpangkat bupati.
Panji panji atau bendera prajurit Mantri jero adalah Purnamasidhi dengan bentuk empat persegi panjang dengan warna dasar hitam dan ditengahnya adalah lingkaran berwarna putih. Purnamsidhi sendiri bersal dari bahasa sansekerta yaitu purnama yang berarti bulan penuh dan sidhiyang berarti sempurna. Sehingga secara secara filosofi purnamasidhi bermakna pasukan yang diharapkan dapat selalu memberikan cahaya dalam kegelapan.

Seragam yang dikenakan oleh pasukan mantri jero adalah Jas buka dengan kain lurik bergaris hitam putih, berbaju dalam putih, bercelana putih, kaos kaki panjang putih dan bersepatu fantopel warna hitam, topi songkok berwarna hitam.

Persenjataan yang dipergunakan prajurit Mantri jero adalah Senapan api dan tombak. Sedangkan perlengkapan alat music yang diperghgunakan berupa tambur, seruling dan terompet Musik sebagai ringan yang dimainkan adalah Mares SLENGGANDIRI, untuk berjalan pelan dengan di gayakan dan Mares PLANGKENAN (RESTOG), untuk berjalan cepat Keberadaan nama prajurit tersebut menjadi nama kampung Mantri jeron.

Apa yang telah dipaparkan di atas merupak keseluruhan identifikasi mengenai seperti apa bentuk, bendera, senjata, maupun hal lainya yang berkaitan dengan para prajurit baik Patang puluh, Jagakrya, Ketanggung, dan Mantrirejo. Sedangkan dalam nilai simbolik yang terdapat pada kostum tersebut antara lain.

Warna yang digunakan pleh para prajurit Kraton memiliki tiga angkatan. Pertama warna secara murni yaitu, menggunakan warna itu sendiri, kedua, warna yang digunakan secara harmoni yang mengungkapkan kenyataan optis, ketiga, warna secara heraldis atau simbolis. Pada kostum prajurit Kraton warna dapat digunakan sebagai nilai simbolis yang 
dapat ditemukan pada pakain dan bendera. Sedangkan dalam penggunaan warnanya menggunakan warna-warna dasar, seperti putih, merah, kuning, hitam, dan biru serta hijau.

Dalam pendapat Yuwono (2009: 54), simbolik Jawa terdapat istilah mancapat dan mancawarna. Maksudnya segala yang ada di dunia dibagi menjadi empat yang tersebar di empat penjuru angin dan satu di tengah sebagai pusatnya. Sama hal tersebut warna hitam terletak di Utara, sementara merah berada di selatan. Warna putih diletakan di Timur, dan Barat memiliki warna kuning. Warna yang berada di pusat merupakan perpaduan antara semua warna itu.

Dari keempat prajurit yang dikaji mereka menggunakan dasar putih hitam sebagai warna dalm pakaianya tapi pada kostum Prajurit Patang puluh memiliki warna merah pada penggunaan busananya. Pada umumnya yang dikenakan identik dengan lurik pada bagian celana maupun kostum yang dikenakan sedanhkan pada bendera memiliki warna yang beraneka ragam.

Warna hitam, dilambangkan dengan Kresna bukan hanya sebuah nama tokoh yang dikenal di Mahabrata namun juga warna hitam, yaitu menggambarkan warna hitam pada kulit Kresna merupakan warna tanah hal ini berkaitan dengan sifat aluaman. Dalam masyarakat Jawa dapar di artikan sebagai keabadian dan kekuatan. Warna ini juga sebagai simbolik di Jawa yang berasosiasi dengan arah utara.

Warna putih, hampir digunakan oleh prajurit Kraton Yogyakarta dalam berbagai bentuk, tapi dapat dilihat pada bagian sekunder. Warna ini memiliki kedekatan dengan makna kesucian. Hubungan putih dengan kesucian sudah lama dalam sejarah. Di dalam struktur pemerintahan kerajaan di Jawaabdi dalem disebut dengan Pamethakan. Istilah ini berasal dari Jawa yang memiliki arti putih. Karena pakaian abdi dalem sendiri merupakan putih yang biasanya mereka juga melalukan acara keagamaan. Dalam simbolik Jawa warna putih memiliki asosiasi arah Timur.

Selain hal tersebut lurik yang terdapat pada para prajurit ini memiliki motif yang berbeda-beda. Para prajurit Patang puluh memiliki motif lutik yang terdapat dua garid putih diikuti dengan garis hitam berukuran sedang. Pada garis putih dipisahkan oleh segaris warna hitam dalam luriknya. Prajurit Jagakarya memiliki motif lurik berseling putih hitam jumlah garis putih sendiri terdiri dari lima garis yang tiap garisnya disisipkan garis hitam pada tiap gari putih yang saling bersanding dengan akan dilanjutkan garis warna hitam yang cukup besar untuk memisahkan dan melanjutkan motif lurik dengan bentuk motif yang sama. Pada prajurit Ketanggung ia memiliki dua motif seling yang berbeda dengan ukuran yang berbeda pula motif pertama, memiliki tiga garis putih dengan tiap garisnya dipisahkan dengan satu garis hitam yang akan diteruskan lagi dengan garis putih, kedua, merupaka garis putih yang simetris yang makin kepusat kemakin hitam, kedua motif tersebut saling bergantian dengan pemisah warna hitam yang memiliki ukuran yang besar untuk memisahkan tiap motif tersebut. Dan pada prajurit Mantri jero yang memiliki motif yang putih lalu lama-lama menuju hitam dan seterusnya.

\section{B. Peran Prajurit Kraton Yogyakarta Sekarang dan Makna Filosofinya}

Meskipun untuk waktu yang lama prajurit Kraton tidak terlibat perang, tetapi pada masa lampau prajurit Kraton merupakan pasukan tangguh dalam menghadapi musuh. Dalam tradisi Jawa terdapat gelar-gelar perang, yaitu, formasi perang prajurit dimedan pertempuran. Nama-nama tersebut 
tidak hanya disesuaikan dengan medan pertempuran maupun musuh tapi sesuai dengan sifat dari senapati perang dalam pertempuran itu.

Dengan adanya pergeseran peran dan fungsinya dari prajurit pertahanan keamanan ke prajurit seremonial akan mempengaruhi perubahan tugas dan kewajiban prajurit Kraton itu yang akan dititik beratkan pada peran pendukung serimonial kraton, seperti upacara jumeneng Sultan, upacara Grebeg, dan tugas seremonial yang lain yang ada di Kraton. Prajurit Kraton memiliki tugas khusus untuk membawa pusaka-pusaka kraton pada saat upacara grebeg.

Makna filosofi dan nilai budaya yang ada pda prajurit kraton Yogyakarta berwawal pada, Sri Sultan Hamengku Buwono I yangmana sangat berpegang teguh akan nilai historis maupun filosofi-religius yang dipercaya dapat berpengaruh pada sikap perilaku dirinya sebagai raja berpengaruh pada kawulanya.

Pada masanya ia, menciptakan prajurit kasultanan sampai penempatan lokasi tempat tinggal prajurit yang menyerupai tapal kuda terhadap lokasi kraton Yogyakarta, hal ini pun tidak lepas dari pertimbnagkan filosofi yang ada. Penempatan yang Sri Sultan Hamengku Buwono I bentul di dalam watak para prajurit kraton adalah, "watak ksatria" atau "wataking satriya ngoyogyakarta" yang dilandasi dengan credo (sesanti) Sawiji, Greget, Sengguh, Ora Mingkuh. Hal ini merupakan falsafat sawiji yang merupakan budaya ide Sri Sultan Hamengku Buwono I. Sesanti ini dipegang sebagai falsafat hidup, pandangan hidup, dan falsafat jodet Mataram. Sawiji memiliki arti orang yang selalu ingat kepada Tuhan Yang Maha Esa, greget berarti seluruh aktivitas dan gairah hidup harsu disalurkan melalui jalan Allah SWT, dan ora Mingkuh artinya, walaupun mengalami kesukaran-kesukaran dalam kehidupan, namun selalu percaya kepada Tuhan Yang Maha Esa.

Kostum yang prajurit yang dikenakan oleh keempat prajurit ini merupakan motif lurik. Yang diketahui kain lurik bukan bahan busana yang semahal kain batik dan filosofi yang ada pada kain ini tidak sekuat kain batik. Kain ini dahulu dikenakan untuk pakaian sehari-hari seperti pada saat pranakan. Maka, makna kain ini cenderung mengambarkan keserderhanaan dan kejujuran.

Kain lurik yang dikenakan oleh para prajurit kraton dinamakan dengan Lurik Ginggang yang memiliki arti renggang yang dikarenakan antara lajur warna yang sama diisi oleh lajur warna yang lain. Namun makna yang ada di dalamnya yang lebih yaitu, kesetiaan prajurit kepada rajanya, dan hubungan antara prajurit jangan sampai adanya kerenggangan.

Sedangkan warna yang ada pada lurik yang mendekati warna abu-abu (abu= awu dalam bahasa Jawa, melambangkan kasih sayang dan restu raja terhadapa prajurit laksana abu yang tidak dapat dibakar oleh api. Namun ada bebrapa pendapat yang memiliki makna yang berbeda-beda yang melambangkan indentitas.

Selain hal tersebut ada pula motif cindhe yang terdapat pada celana yang dikenakan oleh para prajurit. Motif ini merupakan motif tekstil pengaruh India. Penggunaan motif ini dapat diartikan makna teknis sebagai aksen bagi kain-kain yang polos dan batik. Warna ini cenderung warna merah yang memiliki makna keberanian yang disandang oleh para prajurit.

\section{PENUTUP}

Latar belakang adanya prajurit Kraton Yogyakarta terkait dengan konflik yang memunculkan peristiwa "perang Mangkubumen" antara tahun 1746 - 1755 M yang terkait dengan adanya perjanjian Giyanti antara Sri Sunan Paku Buwana III dengan 
Pangeran Mangkubumen. Dalam sejarah mengatakan keberhasilan perjuangan Hamengku Buwana I tidak lepasa dari dukungan aliansi prajurit, kerabat, kelompokkelompok prajurit dibawah pimpinan Rangga Prawirasentika.

Prajurit Kraton yang kita kenal sekarang berjumlah 10 bergada tapi dulu jumlahnya sangat banyak sehingga disebut sebagai pasukan "segelas sepapan karena dapat dipakai untuk menerapkan gelar perang dama sebuah pertempuran sungguhan, tetapi pernah abis karena dibubarkan, dan kemudian muncul lagi.

Dalam pembahasann ini hanya akan membahas mengenai empat bergada, yaitu, Patangpuluh, Jagakarya, Ketanggung, dan Mantrirejo. Sedangkan dalam nilai simbolik yang terdapat pada kostum tersebut antara lain. Dalam simbolik Jawa terdapat istilah mancapat (berasosiasi dengan arah utara, lautan nila, hari pasaran Wage) dan mancawarna. Maksudnya segala yang ada di sunia dibagi menjadi empat yang tersebar di empat penjuru angin dan satu di tengah sebagai pusatnya. Sama hal tersebut warna hitam terletak di Utara, sementara merah berada di selatan. Warna putih diletakan di Timur, dan Barat memiliki warna kuning. Warna yang berada di pusat merupakan perpaduan antara semua warna itu.

Dengan pergeserannya peran dan fungsinya dari prajurit pertahanan keamanan ke prajurit seremonial akan mempengaruhi perubahan tugas dan kewajiban prajurit Kraton itu yang akan dititik beratkan pada peran pendukung serimonial kraton, seperti upacara jumeneng Sultan, upacara Grebeg, dan tugas seremonial yang lain yang ada di Kraton. Prajurit Kraton memiliki tugas khusus untuk membawa pusaka-pusaka kraton pada saat upacara grebeg.

Selain itu makna yang terdapat pada setiap atribut maupun warna-warna yang ia gunakan tidak lepas akan pengaruh dari Sri Sultan Hamengku Buwono I yang sangat berpegang teguh akan nilai historis maupun filosofi-religius yang dipercaya dapat berpengaruh pada sikap perilaku dirinya sebagai raja berpengaruh pada kawulanya.

Dari atas hingga bahwa setiap yang dikenakan memiliki filosofi. Sebagai bentuk pengabdian, kesetian, dan keberanian yang dimiliki oleh para prajurit pada kraton Yogyakarta. Oleh karenanya, kostum prajurit kraton memiliki falsafah hidup dan pandangan hidup yang teguh dan tangguh yang tak mudah gentar akan pengabdiannya. Maka dari itu nilai simbol yang dapat dipetik dari kostum ini adanya nilai budaya yang tak lepas dari, seperti lurik yang saling diteruskan lagi dengan warna lain, penggambaran kesetiaan prajurit dengan tuannya yang jangan sampai akan adanya kerenggangan. Maka dari sini kita dapat belajar dan mengetahui akan makna dan nilai yang ada pada kostum prajurit Patangpuluh, Jagakarya, Ketanggung, dan Mantrirejo.

\section{DAFAR PUSTAKA}

\begin{tabular}{|c|c|}
\hline & $\begin{array}{lll}\text { Karaton } & \text { Ngoyogyakarta Dalam } \\
\text { Setahun. } & \text { Penerbit: "KERTA". } \\
\text { Yogyakarta. } & \end{array}$ \\
\hline $\mathrm{rg}$ & $\begin{array}{l}\text { Asa, Arthur. } 2010 . \quad \text { Pengantar } \\
\text { Semiotika: Tanda-tanda Dalam } \\
\text { Kebudayaan Kontempore., Tiara } \\
\text { Wacana, Yogyakarta. }\end{array}$ \\
\hline Burton, & $\begin{array}{l}\text { Graeme. 1999, Pengantar Untuk } \\
\text { memahami Media dan Budaya } \\
\text { Populer, Penerbit: Jalasutra, } \\
\text { Yogyakarta. }\end{array}$ \\
\hline
\end{tabular}

Creswell, W, John. 2016. Research Design : Pendekatan Metode Kualitatif, Kuantitatif, dan Campuran. Pustaka Pelajar. Yogyakarta. 
Moeleong, J, Lexy. 1988. Metodologi Penelitian Kualitatif : Edisi Revisi. Rosda. Bandung.

Sunarto. 2012. Kesetiaan Abdi Dalem Kraton Ngayogyakarta Hadiningrat : Kebudayaan Jawa. "KEPEL PRES". Yogyakarta.

Strinati, Dominic.2007. Popular Culture : Pengantar Menuju Teori Budaya Populer. Jejak. Bandung.

Suwito, Sri, Yuwono. 2009. Prajurit Kraton Yogyakarta Filosofi dan Nilai Budaya Yang Terkandung Di Dalamnya Dinas Pariwisata dan Kebudayaan Kota Yogyakarta. Yogyakarta.

Strauss, Anselm \& Corbin, Juliet. (2003). Dasar-dasar Penelitian Kualitatif : Tatalangkah dan Teknik-teknik Teoritis Data. Pustaka Pelajar, Yogyakarta.

\section{Webtografi}

Natsir, Mohammad. (2015). Mengenal Lebih Dekat Prajurit Prajurit Kraton Yogyakarta. Dalam google online: didapat dari: http://www.cendananews.com/201 5/05/mengenal-lebih-dekat-prajuritprajurit.html .

Irfantoni. (2016), 10 Nama Wilayah Di Sekitaran Kota Jogja Ini Ternyata Berasal Dari Kesatuan Prajurit Kraton. Dalam google online: didapat dari: http://www.pulsk.com/647767/10Nama-Wilayah-Di-Sekitaran-KotaJogja-Ini-Ternyata-Berasal-DariKesatuan-Prajurit-Kraton .html. 